\title{
Article
}

\section{Nicholas Gordon Martin}

\author{
Georgia Chenevix-Trench \\ Genetics and Computational Biology Department, QIMR Berghofer Medical Research Institute, Brisbane, Queensland, Australia
}

\begin{abstract}
We performed a candidate single-nucleotide polymorphism association study of cleft lip and palate in 1992 which earned more citations than it had subjects $(N=230)$.
\end{abstract}

Keywords: Cleft lip and palate; candidates SNP association study

(Received 17 February 2020; accepted 18 February 2020)

I have been asked to write about 'the significance of a particular aspect of Nick's work on the field of genetics'. I know that others will talk about his contributions to understanding the genetic basis of a wide range of traits, from dizygotic twinning to drug taking, drinking, depression and DNA methylation, but I am perhaps best qualified to comment on his influence on one naïve $\mathrm{PhD}$ student of genetics who turned into his Head of Department. I should point out that probably the only reason he himself is not the HoD is that he refuses to attend any meetings longer than an hour, thereby very efficiently ruling himself out of any administrative role which he would see as merely a distraction from doing what he loves setting up collaborations, nursing along projects, teaching students and red-penning manuscripts.

I was a second-year $\mathrm{PhD}$ student at the Medical College of Virginia when the Reverend Dr Lindon Eaves told us that a mad, bad and dangerous Australian was coming to visit and we should all be very careful. And so, dear Reader, Lindon married us, 2 years later. In retrospect, I had no idea what I was doing, starting down an academic pathway. I am the only scientist in my family, had no idea about the life of a research scientist and had a $\mathrm{PhD}$ supervisor who had a 'light touch', to say the least. Nick was the first person I had met who lived and breathed genetics, who never questioned that research was all that he wanted to do (indeed all that anyone would want to do) and who was confident enough to know that if that is what you want, then it will surely happen. For these reasons and more, he always assumed that we would be doing this together and that we would share the responsibilities of house and family. I am sure it is profoundly irritating to those who might be tempted to dismiss him as an MCP (i.e., a Male Chauvinist Pig - does that term even exist anymore?) when he injects some inflammatory comment to get a rise, to know that he fights to get into the kitchen at night, is better acquainted with the vacuum cleaner than I am, started solo parenting when Hilary was 6 months old and I went off to a conference and won the

\footnotetext{
Author for correspondence: Georgia Chenevix-Trench, Email: Georgia.Trench@ qimrberghofer.edu.au

Cite this article: Chenevix-Trench G. (2020) Nicholas Gordon Martin. Twin Research and Human Genetics 23: 72-73, https://doi.org/10.1017/thg.2020.14

nappy-changing and hanging-up-washing (with baby on hip) contests at her first birthday party.

I come from a long line of writers so fancied myself as pretty competent at sentence construction at least. But, I am sure I was not the first person he reduced to tears by covering the first manuscript I wrote with red-penned comments, although I did realize that he was (usually) right and listened through gritted teeth until he declared that I had 'graduated' from his writing school. Before I finished my $\mathrm{PhD}$, we had decided that we wanted to move to Australia, even though when we first met I told him that I had no interest in going to Australia, and that if someone gave me a ticket, I would trade it in. In 1985, there were so few jobs, anywhere in the world, in statistical genetics that beggars could not be choosers, and when one came up in Brisbane, he had to take it once they had thrown in a post-doc position for me. Back then, Brisbane was a total backwater scientifically (and indeed in other ways, being not much more than a country town), so when we told people we were moving there, I think they thought we must have a criminal record and might as well move to Vladivostok. Such is Nick's incredible optimism, and love for Australia, that he took on the challenge and we came on a one-way ticket to a town to which I had never been where the houses are on stilts, to a post-doc position with no specified supervisor, to a country 'of droughts and flooding rains'. The timing was right because a very right wing state government had left the coffers full, and a long-term Labor government was very supportive of research. But mostly, it was Nick's energy and force of personality that turned Brisbane into a world-class center of complex trait genetics. The list of people who either trained with Nick, or became regular visitors, or are his academic 'grandchildren' is a veritable Who's Who of the field now, and I am sure into the future.

I helped him get his lab running when we first arrived, and we worked together on the genetics of cleft lip and palate. Our candidate single-nucleotide polymorphism study on 117 cases and 113 controls, published in the American Journal of Human Genetics (Chenevix-Trench et al., 1992), was quite a landmark association study for a complex trait and has 241 citations. Not many of his recent papers have more citations than subjects! He is not entirely one-track minded in his professional life, though. When Hilary admitted to wanting to be a geneticist, he said she could be a 
statistical geneticist, a quantitative geneticist or a genetic epidemiologist. And he has even come around to Felicity's career choice - she calls herself the 'black sheep' of the family as a medical doctor - because he knows she is so good at it.

Nick has an incredible knack of seeing the best in those who might otherwise be thought of as (and indeed, often proved to be) ill qualified for the job (like the taxi driver he once gave a job to because he said that he thought that melanoma 'was all about the melacortin 1 receptor') and the Iraqi refugee (an old friend from his $\mathrm{PhD}$ days, then a professor in Mosul) who had never used a keyboard, much less the internet or done a polymerase chain reaction. There is nothing he likes as much as filling the house with students and post-docs, putting on some Schubert or Ali Farka Toure, pouring a stiff gin and tonic or two, cooking a roast lamb with potatoes done to perfection in duck fat (ssshh — don't tell the vegetarians) and winding people up through a fierce (and only semiserious) political argument. One of the best such parties ended with the irreplaceable Leena Peltonen saying 'Neek, I lurve you, every time I meet you I lurve you, but you are stoopid, stoopid and stoopid'!
Despite his devotion to genetics, Nick epitomizes 'work hard and play hard', a culture that is encouraged in Australia. Anyone who has ever doubted his role on the more than 1300 papers he is an author on should see the red pen marks all over our bed sheets - most of them he reads from 5 to $6 \mathrm{am}$. He has been to work almost every Sunday of his working life, but in return, we take off all of January and have just returned from a 6-week holiday in Africa.

It is always difficult to imagine 'what if, but I am confident that if we had not seen that advertisement in Nature for a genetic epidemiologist in Brisbane, one snowy Sunday in Richmond, the field would be a very different place and none of you would have ever heard of the Queensland Institute of Medical Research.

\section{Reference}

Chenevix-Trench, G., Jones, K., Green, A. C., Duffy, D. L., \& Martin, N. G. (1992). Cleft lip with or without cleft palate: Associations with transforming growth factor alpha and retinoic acid receptor loci. American Journal of Human Genetics, 51, 13771385. 